children with urinary tract infections in Gothenburg. It is crucial to be aware of the high incidence of acute pyelonephritis in infants and small children as early treatment is important to prevent renal scarring. Immediate investigation of the urinary tract is performed in all infants and in older children with renal infections to detect obstructive malformations and vesicoureteric reflux. Patients at risk are continuously followed up through adolescence into adulthood and are repeatedly informed about the future risks and the need for early treatment of renal infections. We believe that this is the reason for the rather low rate of complications and the overall good outcome of pregnancies in our subjects. The low rate of legal abortions in the women with urinary infection in childhood compared with the controls may be another measure of the value of this education and the good access to medical care that these patients have had.

We thank Dr Gunilla Sundell for her help in collecting the data, and Nils Gunnar Pehrsson for the statistical calculations. The study was supported by grants from the Gothenburg Medical Society.

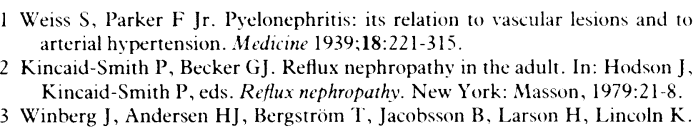

Weiss S, Parker F Jr. Pyelonephritis: its relation to vascular lesions and to arterial hypertension. Medicine 1939;18:221-315.

arteral heperten. Kincaid-Smith P eds Reflux nephropathy. New York: Masson, 1979:21-8. 3 Winberg J, Andersen HJ, Bergströn T, Jacobsson B, Larson H, Lincoln K.

Eipidemiology of ssmptomatic urinary tract infection in childhood. Actu Paediatr Siand 1974;suppl 252:1-20.

4 Jodal U. The natural history of bacteriuria in childhood. Infectious Disease Climics of North America 1987:1:713-29.

5 (iranerus $G$, Aurell $M$. Reference values for $\mathrm{Cr}$-EDTA clearance as a measure of glomerular filtration rate. Scand 7 Clin Lab Intest 1981;41:61 1-6.

6 Hodson CJ, Wilson S. Natural history of chronic pyelonephritic scarring. BrMed F 1965;ii: 191-4.

7 Smellie J, Edwards D, Hunter N, Normand ICS, Prescod N. Vesico-ureteric reflux and renal scarring. Kidney Int 1975;8:65-72.

8 International Reflux Study in Children. International system of radiographic grading of vesicoureteric reflux. Pediatr Radiol 1985;15:105-9.

9 Odén A, Wedel H. Arguments for Fisher's permutation test. Annals of Statistics 1975;3:518-20

10 Bradley JW. Distribution free statistical tests. London: Prentis Hall, 1968.

11 Sacks SH, Roberts R, Verrier-Jones K, Asscher AW, Ledingham JGG. Effeet of symptomless bacteriuria in childhood on subsequent pregnancy. Lancet 1987:ii:991-4.

12 Campbell-Brown M, McFadyen IR, Seal DV, Stephenson ML. Is screenin for bacteriuria worth while? $\mathrm{Br}$. Med f 1987;294:1579-82.

13 Persson K, Kvist-Christensen K. Christensen P, Forsgren A, Jörgensen C Persson P-H. Asymptomatic bacteriuria during pregnancy with special reference to group B streptococci. Scand I Infect Dis 1985;17:195-9.

14 Stenqvist $K$, Dahlén-Nilsson I, Lidin-Janson G, et al. Bacteriuria in pregnancy. Frequency and risk of acquisition. Am 7 Epidemiol 1989;129:372-9.

15 Edwards D, Normand ICS, Prescod N, Smellie J. Disappearance of vesicoureteric reflux during long term prophylaxis of urinary tract infection in children. Br Med f 1977;ii:285-8.

16 Bedoun SN. Morphologic changes in the renal tract in pregnancy. Clin Obstet Gynecol 1985;28:249-56.

17 Mattingly RF, Borkowf HI. Clinical implications of ureteral reflux in pregnancy. Clin Obstet Gynecol 1978;21:863-73.

18 Sandberg T Lidin-Janson G, Svandborg-Eden C. Host response in women with symptomatic urinary tact infection. Scand I Infect Dis 1989;21:67-73.

19 Wuth stmer W a reve 1986. Aust NZ 7 Obstet Gynaecol 1987:27:106-11.

Accepted 2 February 1990
Research Unit, Royal College of Physicians, London NW1 4LE Sheila Howarth, FRCP, coordinator

Cyril Clarke, FRCP, former director

Richard Bayliss, FRCP, former assistant director A G W Whitfield, FRCP, former assistant director

London School of Hygiene and Tropical Medicine, London WC1E 7HT

Joanna Semmence, MSC, postgraduate student M J R Healy, MA, professor of medical statistics

Correspondence to: Sir Cyril Clarke, 43 Caldy Road, West Kirby, Wirral, Merseyside L48 2HF.

Professor Whitfield has since died.

Br.Med f 1990;300:844-7

\title{
Mortality in elderly patients admitted for respite care
}

\author{
Sheila Howarth, Cyril Clarke, Richard Bayliss, A G W Whitfield, Joanna Semmence, M J R Healy
}

\section{Abstract}

Objective-To determine whether admitting elderly patients to hospital to give temporary relief to their carers is associated with increased mortality.

Design-Prospective multicentre study comparing the mortality of patients admitted on a one off or rotational basis with that experienced while they were awaiting admission.

Setting - A wide range of urban and rural district general, geriatric or long stay, and general practitioner hospitals.

Patients -474 Patients aged 70 or over who had 601 admissions.

Main outcome measure-Death.

Results $-16(3.4 \%)$ Of the 474 patients $(2 \cdot 7 \%$ of all 601 admissions) died while in hospital during an average stay of 15.7 days whereas $23(4.9 \%)$ patients died while awaiting admission (average waiting time was $34 \cdot 2$ days). The 16 deaths in hospital and the 23 deaths during the longer waiting period correspond to death rates of 19.9 and 12.5 per 10000 person days respectively. The difference between these of 7.4 is not statistically significant $(95 \%$ confidence interval

-3.6 to $18 \cdot 3)$. The estimated relative risk of dying in hospital is 1.59 but the $95 \%$ confidence interval is wide $(0.84$ to 3.01$)$.

Conclusion-Although the death rates are slightly higher in those admitted to hospital for relief care than in those awaiting admission, the difference was not significant, and the death rate in both groups was reassuringly small.

\section{Introduction}

A study of 69 elderly patients admitted to the Whittington Hospital in London between July 1980 and February 1983 to give relief or a holiday to their carers found that nine $(13 \%)$ died in hospital-all from bronchopneumonia. ${ }^{.}$Other researchers have also observed a high mortality under similar circumstances. DeLargy reported that of 100 patients admitted every 12 weeks for a six week stay 30 died in hospital over an 18 month period. ${ }^{2}$ Twenty four patients died during their first or second temporary admission. This was not considered unusual in the general wards of a geriatric unit. Four $(9 \%)$ of 46 patients entering a geriatric unit in Glasgow for temporary admission died during their stay and two died immediately after returning home. Ten others who returned home were deemed appreciably worse than on admission and eight, excluding the four who died, never returned home because of deterioration.

In correspondence responding to the disturbing report by Rai et al' mortality of 5\% or less was reported in several hospitals admitting patients for temporary care. ${ }^{+7}$ More recently a retrospective study examining whether psychogeriatric patients aged 65 or over had an increased risk of dying when admitted for relief care found that $19(9 \%)$ of 210 patients, admitted for respite care on 218 occasions died in hospital whereas 29 $(13 \cdot 8 \%)$ died elsewhere, giving a relative risk of dying in hospital of $1 \cdot 14$.

We report a prospective study of the risk of death associated with admitting elderly patients for respite care in hospitals throughout the United Kingdom.

\section{Patients and methods}

All patients admitted to the study were aged 70 or over and incapable of looking after themselves, being cared for at home by one or more carers. The study was carried out prospectively over 12 months from February 1987. With the help of geriatricians in several centres patients were recruited from various types of hospital (district general, geriatric long stay, general practitioner, or private nursing home) distributed 


\begin{tabular}{|c|c|c|c|c|c|c|c|c|c|}
\hline \multirow[b]{3}{*}{ Centre } & \multirow[b]{3}{*}{ Hospital } & \multicolumn{3}{|c|}{ Approximate No of beds in 1987} & & & & & \multirow[b]{3}{*}{ Deaths } \\
\hline & & \multirow{2}{*}{$\begin{array}{l}\text { District } \\
\text { general } \\
\text { hospital }\end{array}$} & \multirow[b]{2}{*}{ Geriatric } & \multirow[b]{2}{*}{ Other ${ }^{\star}$} & \multicolumn{2}{|c|}{ No of male } & \multicolumn{2}{|c|}{ No of female } & \\
\hline & & & & & Admissions & Patients & Admissions & Patients & \\
\hline Belfast & Ulster & 499 & 144 & & 7 & 7 & 15 & 15 & \\
\hline Birmingham & $\begin{array}{l}\text { Moseley Hall } \\
\text { West Heath }\end{array}$ & & $\begin{array}{l}241 \\
187\end{array}$ & & $\begin{array}{l}9 \\
3\end{array}$ & $\begin{array}{l}8 \\
3\end{array}$ & $\begin{array}{l}4 \\
1\end{array}$ & $\begin{array}{l}3 \\
1\end{array}$ & 1 \\
\hline Bolton & $\begin{array}{l}\text { Hulton } \\
\text { Bolton General } \\
\text { Blair }\end{array}$ & 851 & $\begin{array}{r}122 \\
38\end{array}$ & & $\begin{array}{l}4 \\
5 \\
1\end{array}$ & $\begin{array}{l}4 \\
5 \\
1\end{array}$ & $\begin{array}{r}3 \\
14 \\
1\end{array}$ & $\begin{array}{r}3 \\
14 \\
1\end{array}$ & \\
\hline Cambridge & $\begin{array}{l}\text { Saffron Walden } \\
\text { Tower } \\
\text { Newmarket General } \\
\text { Chesterton }\end{array}$ & 286 & $\begin{array}{l}84 \\
76\end{array}$ & 108 & $\begin{array}{r}6 \\
2 \\
4 \\
16\end{array}$ & $\begin{array}{r}5 \\
2 \\
1 \\
12\end{array}$ & $\begin{array}{c}5 \\
19 \\
41\end{array}$ & $\begin{array}{r}\frac{5}{9} \\
25\end{array}$ & 1 \\
\hline Cardiff & $\begin{array}{l}\text { Glan Ely } \\
\text { Sully } \\
\text { St David's }\end{array}$ & 171 & $\begin{array}{r}48 \\
237\end{array}$ & & $\begin{array}{r}15 \\
4 \\
4\end{array}$ & $\begin{array}{r}11 \\
3 \\
4\end{array}$ & $\begin{array}{r}26 \\
2 \\
9\end{array}$ & $\begin{array}{r}23 \\
2 \\
7\end{array}$ & 1 \\
\hline Carain & $\begin{array}{l}\text { Lansdowne } \\
\text { Royal Infirmary }\end{array}$ & & 80 & & $\begin{array}{l}4 \\
2 \\
1\end{array}$ & $\begin{array}{l}4 \\
1\end{array}$ & 7 & 6 & 2 \\
\hline Cromer & $\begin{array}{l}\text { St Michael's } \\
\text { Fletcher }\end{array}$ & & 66 & 117 & $\begin{array}{r}24 \\
5\end{array}$ & $\begin{array}{l}7 \\
3\end{array}$ & $\begin{array}{l}7 \\
4\end{array}$ & $\begin{array}{l}4 \\
2\end{array}$ & \\
\hline Falkirk & $\begin{array}{l}\text { Windsor } \\
\text { Lochgreen } \\
\text { Falkirk and District Royal }\end{array}$ & & $\begin{array}{r}115 \\
85\end{array}$ & & $\begin{array}{r}7 \\
11\end{array}$ & $\begin{array}{r}7 \\
10\end{array}$ & $\begin{array}{l}20 \\
10\end{array}$ & $\begin{array}{l}20 \\
10\end{array}$ & 2 \\
\hline & Infirmary & 454 & & & 7 & 6 & 13 & 13 & 1 \\
\hline Glasgow & Meanskirk & 539 & & & 20 & 20 & 68 & 65 & 2 \\
\hline Ipswich & $\begin{array}{l}\text { Stow Lodge } \\
\text { St Edmund's Nursing Home } \\
\text { Felixstowe General } \\
\text { Aldeburgh Cottage }\end{array}$ & & 14 & $\begin{array}{r}111 \\
28 \\
17\end{array}$ & $\begin{array}{r}- \\
1 \\
2\end{array}$ & $\overline{-}$ & $\begin{array}{r}1 \\
40\end{array}$ & $\begin{array}{r}1 \\
31\end{array}$ & \\
\hline $\begin{array}{l}\text { London } \\
\text { New Forest }\end{array}$ & $\begin{array}{l}\text { Nelson } \\
\text { Lymington Infirmary }\end{array}$ & & $\begin{array}{r}112 \\
52\end{array}$ & & $\begin{array}{r}27 \\
7\end{array}$ & $\begin{array}{r}21 \\
5\end{array}$ & $\begin{array}{l}30 \\
11\end{array}$ & $\begin{array}{r}25 \\
6\end{array}$ & 2 \\
\hline Southampton & Moorgreen & & & 245 & 15 & 12 & 13 & 10 & 1 \\
\hline Taunton & Williton and District & & 56 & & 12 & 5 & 16 & 6 & 2 \\
\hline & Total & & & & 221 & 167 & 380 & 307 & 16 \\
\hline
\end{tabular}

* Other types of hospital include long stay and general practitioner hospitals.

†St Edmund's is run by the Women's Royal Voluntary Service for women only.

across the country and including patients living in rural and urban areas (see table I). The type of accommodation was also recorded (for example, large or small ward, single or double bedroom)

An admission for respite care, which would normally last for two and at the most three weeks, was defined as one arranged to allow the carers to take a prearranged holiday or rest that would be possible only if the patient was admitted to hospital. Admission could be prearranged on either a one off or regular rotational basis. Only those who were in a stable condition, as ascertained from reports of doctors and carers, were included. The interval between the booking and admission was normally at least one week for rotational admissions and four weeks for others, but exceptions were allowed if the patient's condition had not deteriorated or become unstable.

Information on the patient was obtained from five different colour coded forms: $(a)$ notification from the

TABLE II - Details of patients who died during admission for respite care

\begin{tabular}{|c|c|c|c|c|c|c|}
\hline \multirow[b]{2}{*}{ Case No } & \multirow[b]{2}{*}{$\begin{array}{c}\text { Age } \\
\text { (years) }\end{array}$} & \multirow[b]{2}{*}{ Sex } & \multicolumn{3}{|c|}{ Time (days) between } & \multirow[b]{2}{*}{ Cause of death and comments } \\
\hline & & & $\begin{array}{l}\text { Booking and } \\
\text { admission }\end{array}$ & $\begin{array}{l}\text { Admission } \\
\text { and death }\end{array}$ & $\begin{array}{l}\text { Booking } \\
\text { and death }\end{array}$ & \\
\hline 1 & 71 & $M$ & 10 & 11 & 21 & $\begin{array}{l}\text { Bronchopneumonia, extension of existing stroke } \\
\text { on day after admission }\end{array}$ \\
\hline 2 & 70 & M & 7 & 8 & 15 & Haematemesis, hemiplegia \\
\hline 3 & 81 & $\mathrm{~F}$ & 10 & 5 & 15 & $\begin{array}{l}\text { Chronic lymphatic leukaemia, admission } \\
\text { coincided with need for terminal care }\end{array}$ \\
\hline 4 & 82 & $M$ & 7 & 7 & 14 & $\begin{array}{l}\text { Chronic obstructive airways disease, myocardial } \\
\text { infarction }\end{array}$ \\
\hline 5 & 90 & $\mathrm{~F}$ & 3 & 3 & 6 & Myocardial infarction \\
\hline 6 & 86 & $\mathrm{~F}$ & 18 & 15 & 33 & Myocardial infarction \\
\hline 7 & 100 & $\mathrm{~F}$ & 4 & 31 & 35 & Pneumonia \\
\hline 8 & 86 & M & 28 & 12 & 40 & Bronchopneumonia \\
\hline 9 & 79 & $\mathrm{~F}$ & 33 & 14 & 47 & $\begin{array}{l}\text { Myocardial infarction on day of proposed } \\
\text { discharge }\end{array}$ \\
\hline 10 & 72 & M & 31 & 23 & 54 & $\begin{array}{l}\text { Bronchopneumonia, longstanding hemiplegia, } \\
\text { deterioration led to prolonged admission }\end{array}$ \\
\hline 11 & 89 & $\mathrm{~F}$ & 51 & 10 & 61 & Cardiac arrest. Stroke \\
\hline 12 & 73 & $\mathrm{M}$ & 12 & 93 & 105 & Stroke, bronchopneumonia \\
\hline 13 & 72 & $\mathrm{~F}$ & 35 & 20 & 55 & Bronchopneumonia. Carcinoma of the lung \\
\hline 14 & 85 & $\mathrm{~F}$ & 28 & 44 & 72 & Stroke during admission \\
\hline 15 & 83 & M & 70 & 25 & 95 & Bronchopneumonia, stroke \\
\hline 16 & 83 & $\mathrm{~F}$ & 20 & 24 & 44 & Myocardial infarction, senile dementia \\
\hline
\end{tabular}

hospital of a respite admission being arranged; $(b)$ a report from the carer on the patient's condition at the time of admission to hospital; (c) a report by the hospital doctor on the patient's condition when admitted; (d) a report by the hospital doctor at discharge outlining the patient's condition while in hospital with particular attention to any improvement or deterioration during the stay, and $(e)$ a report from the carer submitted within six weeks of the patient's return home.

Our aim was to enlist 500 or more patients, expecting to observe around 50 deaths. In fact, we studied 694 admissions but 93 of these had to be excluded because of recording errors ( 33 cases), cancelled admission (32), admission for $<14$ days $(10)$, or medical instability or deterioration (18). If an admission continued beyond three weeks for medical or other reasons the patient was still included in the study. Thus the final analysis was made on 601 actual or intended admissions relating to 474 patients. Patients were categorised as survivors, died in hospital during respite care, or died awaiting admission for respite care.

\section{Results}

Sets of forms that could be analysed, although not necessarily complete, were returned for a total of 474 patients who had had 601 admissions during the survey (table I). There were 221 admissions of 167 men (31 more than once) and 380 admissions of 307 women (56 more than once). Thus most patients were admitted on a one off basis. Sixteen $(3 \cdot 4 \%)$ patients $(2 \cdot 7 \%$ of all admissions) died in hospital during respite care and 23 (4.9\%) patients died while awaiting admission for respite care. Details of those who died and the causes of death are shown in tables II and III.

Dates of booking, admission, and discharge were available for 499 of the 601 admissions. The average time spent waiting for.admission was $34 \cdot 2$ days and that spent in hospital averaged 15.7 days. The 23 
deaths during the waiting period and the 16 deaths in hospital were calculated to give a mortality of 12.5 and 19.9 per 10000 person days respectively. The difference between the two rates of $7 \cdot 4$ was not significant $(95 \%$ confidence interval $-3 \cdot 6$ to $18 \cdot 3)$. The estimated relative risk of dying in hospital was 1.59 , but the $95 \%$ confidence interval was wide $(0.84$ to $3 \cdot 01)$.

Information on the occurrence of common complications (respiratory and urinary tract infections, bedsores) and the type of accommodation to which the patient was admitted was available for 492 admissions. We found no evidence that the type of accommodation influenced the incidence of these complications (table IV).

We have no accurate information on how the patients settled in hospital, but only 10 patients discharged themselves or were removed by their carers and 127 were admitted for respite care more than once.

We obtained information on changes in patients' condition during their stay in hospital for 325 admissions. In the 213 cases about which the hospital doctor and carer agreed the patient's condition was unchanged in 188 cases, improved in 17, and deteriorated in eight. Doctors and carers disagreed in 112 instances. Of these the doctor noted improvement but the carer no change in 21 cases, the doctor noted no change but the carer improvement in 38 , the doctor observed no change but the carer noted deterioration in 38 , the doctor found deterioration but the carer no change in eight, the doctor noted improvement but the carer deterioration in six, and the doctor noted deterioration but the carer noted improvement in one. These observations have an inbuilt source of inaccuracy

TABLE III - Details of patients who died while awaiting admission for respite care

\begin{tabular}{|c|c|c|c|c|}
\hline Case No & $\begin{array}{c}\text { Age } \\
\text { (years) }\end{array}$ & Sex & $\begin{array}{c}\text { Interval } \\
\text { between } \\
\text { booking and } \\
\text { death (days) }\end{array}$ & Cause of death and comments \\
\hline 17 & 85 & $\mathrm{~F}$ & 6 & Stroke \\
\hline 18 & 90 & $\mathrm{~F}$ & 70 & Chronic renal failure \\
\hline 19 & 77 & $\mathrm{~F}$ & 7 & Bronchopneumonia, stroke \\
\hline 20 & 81 & $\mathrm{~F}$ & 42 & $\begin{array}{l}\text { Bronchopneumonia, diverticulitis } \\
\text { with rectovaginal fistula }\end{array}$ \\
\hline 21 & 96 & $\mathrm{~F}$ & 5 & $\begin{array}{l}\text { Peritonitis from ruptured } \\
\text { diverticulitis }\end{array}$ \\
\hline 22 & 90 & $\mathrm{~F}$ & 11 & Bronchopneumonia \\
\hline 23 & 87 & $\mathrm{~F}$ & 34 & Stroke \\
\hline 24 & 85 & $\mathrm{~F}$ & 6 & $\begin{array}{l}\text { Bronchopneumonia, hereditary } \\
\text { telangiectasia }\end{array}$ \\
\hline 25 & 80 & $M$ & 3 & Stroke \\
\hline 26 & 85 & $\mathrm{~F}$ & 31 & Carcinoma of vulva, inanition \\
\hline 27 & 79 & $\mathrm{~F}$ & 14 & Myocardial infarction \\
\hline 28 & 88 & $\mathrm{~F}$ & 23 & $\begin{array}{l}\text { Acute admission for stroke and } \\
\text { died shortly afterwards }\end{array}$ \\
\hline 29 & 90 & $\mathrm{~F}$ & 53 & $\begin{array}{l}\text { Renal failure, chronic } \\
\text { pyelonephritis }\end{array}$ \\
\hline 30 & 91 & $\mathrm{~F}$ & 0 & Died on the day booking was made \\
\hline 31 & 90 & $\mathrm{~F}$ & 10 & Stroke, bronchopneumonia \\
\hline 32 & 87 & $\mathrm{~F}$ & 17 & Stroke \\
\hline 33 & 75 & $M$ & 21 & Bronchopneumonia, parkinsonism \\
\hline 34 & 87 & $\mathrm{~F}$ & 12 & Myocardial infarction \\
\hline 35 & 76 & $M$ & 11 & $\begin{array}{l}\text { Stroke, bronchopneumonia. } \\
\text { Emergency admission }\end{array}$ \\
\hline 36 & 80 & M & 24 & $\begin{array}{l}\text { Bronchopneumonia, died four days } \\
\text { before next arranged admission }\end{array}$ \\
\hline 37 & 97 & $\mathrm{~F}$ & 8 & Stroke \\
\hline 38 & 91 & $\mathrm{~F}$ & 23 & Hypertensive heart failure \\
\hline 39 & 87 & $\mathrm{~F}$ & 18 & Bronchopneumonia \\
\hline
\end{tabular}

*Those who died in hospital had been taken ill at home and had been admitted for acute conditions not for respite care.

TABLE IV - Number (percentage) of main complications arising during 492 admissions for respite care according to patients' accommodation

\begin{tabular}{lrccc}
\hline & $\begin{array}{c}\text { Large } \\
\text { ward }\end{array}$ & $\begin{array}{c}\text { Small } \\
\text { ward }\end{array}$ & $\begin{array}{c}\text { Shared } \\
\text { room }\end{array}$ & $\begin{array}{c}\text { Single } \\
\text { room }\end{array}$ \\
\hline Infection of lungs or bronchi & $11(6 \cdot 3)$ & $5(2 \cdot 6)$ & $4(6 \cdot 4)$ & $2(3 \cdot 4)$ \\
Infection of urinary tract & $\begin{array}{r}8 \cdot \cdot 5) \\
3(1 \cdot 7)\end{array}$ & $\begin{array}{l}7(3 \cdot 6) \\
4(2 \cdot 1)\end{array}$ & $\begin{array}{l}2(3 \cdot 2) \\
1(1 \cdot 6)\end{array}$ & $\begin{array}{l}1(1 \cdot 7) \\
\text { Bedsores }\end{array}$ \\
\hline Total admissions & 176 & 194 & 63 & 59 \\
\hline
\end{tabular}

because the doctors assessed patients at the time of discharge from hospital whereas the carer's assessment was given up to six weeks later.

\section{Discussion}

The mortality of $3 \cdot 4-4 \cdot 9 \%$ found in this study is neither unexpected nor unacceptable in a group of elderly patients already so handicapped that they were unable to look after themselves. This low overall mortality should reassure patients, their carers, and the general public that respite care is not a cause for alarm. Although the mortality was somewhat greater for patients during hospital admission than at home, the increase was not significant.

The lower mortality during admissions for respite care in recent years is probably due to several factors including fewer severely ill patients being admitted, exclusion from the study of unstable patients who were clearly deteriorating, a greater awareness of patients' needs, and improved treatment of patients with fewer being admitted to hospitals for long term care as geriatrics has become a specialist subject.

Our study had several shortcomings. Ninety three admissions had to be excluded from the analysis, 33 because of inaccurate documentation. We may also have required the completion of too many forms, which were too complicated for the hospital staff and carers.

We hope this survey will encourage carers to take adequate breaks. Caring for an elderly person at home costs the carer both in economic and health terms. Nevertheless, care at home is cheaper than in hospital ${ }^{4}$ and it saves much government money at the expense of the carer's career, leisure time, finances, and family life. Admitting an invalid to a private nursing home is beyond the means of most people. Studies of carers have shown that they are under much physical and mental stress ${ }^{1011}$ and that they are often elderly themselves (range 23 to 89 years, mean 61 years). ${ }^{1 .}$

Other steps are needed to make the carers' task easier, especially as help for carers varies regionally. ${ }^{4}$ Although charities, such as the National Council for Carers, operate schemes and provide support, over the whole of Britain the number of home help hours provided by the social services has decreased by $13.6 \%$, and in many areas home helps now have to be paid for by the carer. ${ }^{10}$ Furthermore, support is less likely if the dependant lives with the carer especially if the carer is female. ${ }^{12}$

Perhaps the most promising development is that the Independent Living Fund will play an increasing part in funding carers or domestic help for the elderly, thus improving the quality of community care and diminishing the need for long term hospital treatment. $^{13}$

We thank all the consultants, junior medical and nursing staff, and social and other workers who participated in this survey. Professor Whitfield contributed much to the design of this study.

\footnotetext{
I Rai GS, Bielawska C, Murphy PJ, W'right G. Hazards for elderly people admitted for respite "holidas admissions", and social care "social admis. admitted for respite "holiday admi

2 DeLargy J. Six weeks in: six weeks out. A geriatric hospital scheme for rehabilitating the aged and relieving their relatives. Lancet 1957;i:418-9

3 Isaacs B. Thompson J. Holiday admissions to a geriatric unit. Lancet 1960;: ;:969-71

+ McAlpine CH. Lennox I, Ruherts M. Hazards for elderly people admitted for respite and social care. Br.Hed $\mathcal{F}$ 1986;292:481

5 Lenton RJ, Murdoch PS, Simpson A. Hazards for elderly people admitted for respite and social care. BrMed F 1986;292:482.

6 Power MJP, McConnell G, Taylor I. Hazards for elderly people admitted for respite and social care. Br Med f 1986;292:482.

Burston GR. Hazards for elderly people admitted for respite and social care.

Br.Med F 1986;292:482-3.
8 Selley C, Campbell M. Relief care and risk of death in psychogeriatric patients. Br.Med J 1989;298:1223.

9 Semmence J. Report on the study by the Research Unit of the Roval College of Physicians of London on "holiday" relief admissions for the elderly: a report
} 
towards the degree of Master of Science in Medical Statistics. London: London School of Hygiene and Tropical Medicine, 1988. $51 \mathrm{pp}(\mathrm{MSc}$ report.)

10 Rickford $\mathrm{F}$. The decision every woman dreads. Living Magazine 1988;Sep: 54-7.

1 Anderson R. The unremitting burden on carers. Br Med f 1987;294:73.

12 Levin E, Sinclair I, Gorach P. The supporters of confused elderly persons at home. In: Families, services and confusion in old age: report of the Institute for Social Work to the Department of Health and Social Securty. London: Avebury-Gower, 1989

13 Black D. The independent living fund: helping to make a reality of community care. Br Med f 1989;298:1540.

(Accepted 22 January 1990)

\section{Comparison of Teflon cannulas and metal needles for subcutaneous infusion in terminal care: a pilot study}

\section{S Youssef, R E Atkinson}

Ashgate Hospice, Old Brampton, Chesterfield S42 7JE

M S Youssef, FCANAES, senior registrar in anaesthesia R E Atkinson, FCANAES, medical director

Correspondence to: Dr Atkinson.

BrMed f 1990;300:847
Continuous subcutaneous infusion of narcotics and other drugs has been increasingly used in terminal care to control symptoms.' Failure of the infusion may be due to failure of the machine or battery, blockage of the tubing or cannula, disconnection, or a local skin reaction. Local skin reactions, such as erythema, swelling, and abscesses, are the principal problem; they may affect drug absorption profiles and necessitate frequent resiting of the cannula. ${ }^{2}$ Drugs are commonly administered through a subcutaneous indwelling butterfly needle, but a metal needle may itself cause local reactions. British Standard 4843 states, "Materials used in manufacturing cannulae must not be detrimental to any body tissues." We therefore determined whether the incidence of local skin reactions could be reduced by giving the drugs through Teflon cannulas.

\section{Patients, methods, and results}

We compared Teflon cannulas (Jelco standard wire gauge 22; Critikon, Ascot, Berkshire) and butterfly metal needles (standard wire gauge 23; Abbott, Ireland) under conditions of normal clinical practice. Patients were randomised to have either a butterfly needle or a Teflon cannula inserted under aseptic conditions, and the site of insertion was covered with a transparent dressing (Opsite; Smith and Nephew, Hull). The site was observed daily by nursing staff. When a complication occurred the needle or cannula was removed and the infusion continued through the alternative device. The trial was concluded when the patient had had both a needle and a Teflon cannula removed, although the subcutaneous infusion was continued as required for clinical management.

For each patient we used a standard form to record demographic data; type of cancer; date, time, and site of insertion of the needle and cannula; and reasons for removing the needle and cannula. The dose of drugs infused each day was also recorded. Twenty patients entered the trial, 12 of whom completed it (table).
Eight patients died before either the first or second infusion device had to be removed.

The periods for which the needle and cannula were in place were comparable (Wilcoxon's rank sum test). The incidence of local complications was compared with McNemar's test. Signficantly fewer patients experienced swelling when a Teflon cannula was inserted $(p<0.05)$, but the incidence of erythema associated with the cannula, although less than that associated with the butterfly needle, was not significantly different $(p=0 \cdot 1)$. The high incidence of mechanical problems with the Teflon cannulas especially kinking and displacement, however, meant that they needed replacing as often as the metal needles, and acute withdrawal symptoms resulted in one patient.

\section{Comment}

A metal cannula under the skin can cause trauma in the underlying tissues, and partly for this reason they are no longer used for continuous intravenous infusion. Ventafridda et al suggested that using Teflon cannulas to give drugs subcutaneously may eliminate the problems of skin reactions,' but this suggestion has never been examined. We found the mechanical problems with the Teflon cannulas to be the major drawback. Partial withdrawal and hence kinking of the cannula that we used may be due to the design of its hub as it does not have wings for stabilisation. We chose this type of cannula in preference to the more practical winged Teflon cannula because sepsis may occur at the injection port of the winged type. ${ }^{4}$

As Teflon cannulas were associated with fewer skin reactions we suggest that winged Teflon cannulas should be evaluated further: bolus injections at the port should be avoided or a cannula without an injection port could be assessed. This might overcome the mechanical problems while retaining the advantages.

We thank the nursing staff of this hospice and the community and Macmillan nurses in Chesterfield for their cooperation.

1 Ventafridda V, Spoldi E, Caraceni A, et al. The importance of continuous subcutaneous morphine administration for cancer pain control. Pain Clinic 1986;1:47-55.

2 Dover SB. Syringe driver in terminal care. Br Med $\mathcal{f}$ 1987;294:553-5.

British Standards Institution. Sterile intravenous cannulae for single use. London: BSI, 1972. (British standard 4843.)

4 Oberhammer EP. Contamination of injection ports on intravenous cannulae. Lancet 1980;ii: 1027-8.

(Accepted 3 January 1990)

Local complications in 12 patients who received drugs through Teflon cannula and metal butterfly needle

\begin{tabular}{|c|c|c|c|c|c|c|}
\hline \multirow[b]{2}{*}{$\begin{array}{c}\text { Case } \\
\text { No }\end{array}$} & \multicolumn{3}{|c|}{ Teflon cannula } & \multicolumn{3}{|r|}{ Metal needle } \\
\hline & Site & $\begin{array}{l}\text { No of days } \\
\text { in place }\end{array}$ & Reason for removal & Site & $\begin{array}{l}\text { No of days } \\
\text { in place }\end{array}$ & Reason for removal \\
\hline 1 & Chest wall & 2 & Removed accidentally & Abdomen & 2 & Blocked \\
\hline 2 & Chest wall & 2 & Removed accidentally & Abdomen & 2 & Blocked \\
\hline 3 & & 2 & Cannula kinked and blocked & Upper arm & 6 & Erythema and swelling \\
\hline 4 & Upper arm & 12 & Erythema and swelling & Chest wall & 2 & Frythema and swelling \\
\hline 5 & Upper arm & 2 & Cannula kinked and blocked & Upper arm & 4 & Erythema and swelling; patient complained of soreness \\
\hline 6 & Upper arm & 4 & Erythema, cannula kinked & Upper arm & 6 & Erythema and swelling \\
\hline 7 & Upper arm & 6 & Cannula kinked & Upper arm & $i$ & Swelling \\
\hline 8 & Upper arm & $\begin{array}{l}0 \\
1\end{array}$ & Removed accidentally & Upper arm & 2 & Tube blocked and bleeding at site \\
\hline 9 & Upper arm & 2 & Erythema and swelling & Upper arm & 1 & Ervthema and swelling \\
\hline 10 & Upper arm & 2 & Cannula kinked & Upper arm & 4 & Erythema and swelling \\
\hline 11 & Upper arm & 3 & Removed accidentally & Upper arm & 7 & Erythema and swelling \\
\hline 12 & Upper arm & 7 & Cannula kinked & Upper arm & 7 & Removed accidentally \\
\hline
\end{tabular}

${ }^{\star} p<0.05$ for swelling, $p=0.1$ for erythema, $50 \%$ incidence of kinking with Teflon cannulas. 